Економічні науки: збірник наукових прачь Луиького національного технічного університету. Серія "Регіональна економіка". Випуск 17 (67). Редкол.: відп. ред. к.е.н., професор І.В. Кривов'язюк. Луиьк: ІВВ Луцького НТУ, 2020. 348 с.

УДК 331.101

Дзямулич М.I., к.е.н., доцент

Урбан О.А., к.е.н., доцент

Луцький національний технічний університет

\title{
ОЦІНКА ЕФЕКТИВНОСТІ УПРАВЛІННЯ ПЕРСОНАЛОМ ПІДПРИЄМСТВА В УМОВАХ СТАЛОГО РОЗВИТКУ
}

В статті розглянуто специфіку сучасних підходів до оцінки ефективності управління персоналом підприємств в умовах сталого розвитку. Визначено проблеми вибору та застосування дієвих критеріїв оцінки ефективності управління персоналом, актуалізовано використання опосередкованих критеріїв ефективності, запропоновано підходи щодо проведення даної оцінки відносно загальної економічної ефективності діяльності підприємства.

оцінка ефективності.

Ключові слова: персонал, ефективність, управління персоналом,

Dziamulych M.I., Urban O.A.

\section{EVALUATION OF EFFICIENCY OF PERSONNEL MANAGEMENT OF THE ENTERPRISE IN CONDITIONS OF SUSTAINABLE DEVELOPMENT}

The article considers the specifics of modern approaches to assessing the effectiveness of personnel management of enterprises. The problems of selection and application of effective criteria for assessing the effectiveness of personnel 
Економічні науки: збірник наукових прачь Луиького національного технічного університету. Серія "Регіональна економіка". Випуск 17 (67). Редкол.: відп. ред. к.е.н., професор І.В. Кривов’язюк. Луцьк: ІВВ Луцького НТУ, 2020. 348 с.

management are identified, the use of indirect efficiency criteria is updated, approaches to this assessment are proposed in relation to the overall economic efficiency of the enterprise.

The efficiency of the personnel of the enterprise, of course, can not exist by itself, as it is a consequence of purposeful management of the entity, which begins with the process of selecting the required level of quality and qualification and ends with assessing the effectiveness of its use directly in production. Thus, it can be argued that in general, the efficiency of staff use is a complex concept and includes a range of measures aimed at improving productivity and consisting of a number of gradual elements of economic activity of the entity. In this aspect, the most important is the activity of the enterprise to manage the efficiency of its own employees in order to ensure maximum profitability of its activities. Thus, there is a need for a detailed study of aspects of the enterprise related to the direct assessment of the effectiveness of personnel management. In practice, such activities are to assess the total costs and results of management activities aimed at improving the efficiency of the personnel of the enterprise, as well as to compare these results with the general results of the operation of the entity for a certain period.

In practice, to directly assess the effectiveness of personnel management of the enterprise uses a set of methods aimed at improving the efficiency of the personnel of the enterprise. At the same time, there is no unified method of such assessment, as production conditions and a variety of requirements for employees of different skill levels make it impossible to form uniform requirements for labor efficiency both in production and in the analytical activities of general functional units. Business entities additionally have a need for effective planning of measures aimed at improving the efficiency of management and use of personnel, due to the need to form plans for strategic development of the enterprise. At the same time, the available tools are sufficient not only for planning, but also for effective management of employee performance.

In addition, an important aspect of assessing the effectiveness of enterprise personnel management is planning and encouraging staff to achieve certain quality performance indicators, which include both individual goals of strategic development of the enterprise and identified key performance indicators, which are usually formed within the KPI system. The general efficiency of use of the personnel of the enterprise in practice is considered as purposeful achievement of the concrete results defined in the strategic plan. In this case, the effectiveness of staff can be measured using specific methods and using specific indicators, the main of which is the overall productivity of staff. Therefore, the activities of the enterprise to establish an effective and efficient personnel management system is one of the most important tasks in terms of achieving the strategic goals of the entity.

Key words: personnel, efficiency, personnel management, efficiency assessment. 

університету. Серія "Регіональна економіка". Випуск 17 (67). Редкол.: відп. ред. к.е.н., професор І.В. Кривов’язюк. Луцьк: ІВВ Луцького НТУ, 2020. 348 с.

Дзямулич Н.И., Урбан О.А.

\section{ОЦЕНКА ЭФФЕКТИВНОСТИ УПРАВЛЕНИЯ ПЕРСОНАЛОМ ПРЕДПРИЯТИЯ В УСЛОВИЯХ УСТОЙЧИВОГО РАЗВИТИЯ}

В статье рассмотрена специфика современных подходов к оценке эффективности управления персоналом предприятий в условиях устойчивого развития. Определены проблемы выбора и применения действенных критериев оценки эффективности управления персоналом, актуализирован использования косвенных критериев эффективности, предложены подходы по проведению данной оценки относительно общей экономической эффективности деятельности предприятия.

Ключевые слова: персонал, эффективность, управление персоналом, оценка эффективности.

Постановка проблеми у загальному вигляді та ії зв'язок 3 важливими науковими та практичними завданнями. Ефективність використання персоналу підприємства, безумовно, не може існувати сама по собі, оскільки це є наслідок цілеспрямованої діяльності менеджменту суб' єкта господарювання, яка розпочинається з процесу підбору персоналу необхідного рівня якості та кваліфікації i закінчується оцінкою ефективності його використання безпосередньо у процесі виробництва. Таким чином, можна стверджувати, що загалом ефективність використання персоналу є складним поняттям і включає в себе цілий комплекс заходів, які спрямовані на підвищення результативності праці і складаються 3 певного числа поступових елементів господарської діяльності суб'єкта господарювання. В даному аспекті найбільшого значення займає безпосередньо діяльність підприємства по управлінню ефективністю використання власних працівників 3 метою забезпечення максимальної прибутковості його діяльності.

Отже, виникає потреба дослідження діяльності підприємства, пов'язаної з оцінкою ефективності управління персоналом. На практиці така діяльність полягає в оцінці загальних затрат та одержаних результатів управлінської діяльності, спрямованої на підвищення ефективності 
Економічні науки: збірник наукових прачь Луиького національного технічного університету. Серія "Регіональна економіка". Випуск 17 (67). Редкол.: відп. ред. к.е.н., професор І.В. Кривов'язюк. Луиьк: ІВВ Луцького НТУ, 2020. 348 с.

використання персоналу підприємства, а також у співставленні цих одержаних результатів із загальними підсумками функціонування суб'єкта господарювання за визначений період.

Аналіз останніх досліджень, у яких започатковано вирішення проблеми. Дослідження проблем оцінки ефективності управління персоналом підприємства не є новим для вітчизняної науки і дана проблематика широко розкрита у працях таких українських дослідників, як Л.В. Балабанова, Є.П. Качан, О.В. Крушельницька, В.Г. Никифоренко, О.В. Сардак, Г.О. Швиданенко та ін. Проте, в умовах посилення інтернаціоналізації української економіки під випливом глобалізаційних процесів, а також у зв'язку з проникненням на вітчизняний ринок крупних іноземних компаній внаслідок політики євроінтеграції, відбуваються суттєві зміни в підходах до оцінки ефективності управління персоналом, що потребує додаткового дослідження його специфіки.

Цілі статті. Метою роботи $є$ визначення проблем, пов' язаних з необхідністю формування нових підходів до оцінки ефективності управління персоналом в умовах глобалізаційних впливів та загального поширення технологічних новацій, що призводить до трансформації самої системи управління персоналом на підприємствах

Викладення основного матеріалу дослідження 3 повним обгрунтуванням отриманих наукових результатів. для безпосередньої оцінки ефективності управління персоналом підприємства використовується цілий комплекс методів, спрямованих на підвищення ефективності використання персоналу підприємства. При цьому відсутня якась уніфікована методика такої оцінки, оскільки виробничі умови та різноманіття вимог, які ставляться до працівників різного рівня кваліфікації, унеможливлюють формування єдиних вимог щодо ефективності праці як на виробництві, так і при здійсненні аналітичної діяльності загальних функціональних підрозділів.

Тому для практичної оцінки ефективності управління персоналом підприємства використовується система критеріїв, які характеризують загальну успішність діяльності по 
Економічні науки: збірник наукових прачь Луиького національного технічного університету. Серія "Регіональна економіка". Випуск 17 (67). Редкол.: відп. ред. к.е.н., професор І.В. Кривов'язюк. Луиьк: ІВВ Луцького НТУ, 2020. 348 с.

управлінню ефективністю персоналу без конкретизації показників. На основі зазначених критеріїв підприємство може проводити конкретні уточнення показників ефективності управління персоналом підприємства, виходячи з особливостей його функціонування та специфіки організації виробничого процесу. В даному аспекті підприємства застосовують уже загальновідомі показники, які піддаються конкретному вимірюванню та обрахунку i дозволяють не лише вартісно оцінювати ефективність діяльності окремого працівника або підрозділу, але й планувати на майбутні періоди конкретні завдання стосовно виконання виробничої програми та досягнення працівниками поставлених у стратегічному чи поточному плані підприємства цілей.

Для конкретизації таких показників використовуються загальні показники економічної ефективності, оцінюється рівень задоволеності працівників оплатою та умовами праці. Останнім часом широкого поширення в оцінці ефективності діяльності персоналу набуло застосування опосередкованих критеріїв ефективності персоналу, таких, як якість та безпека праці або результати опитування працівників шляхом анкетування тощо.

Крім того у суб'єктів господарювання існує потреба у плануванні заходів, спрямованих на підвищення ефективності управління і використання персоналу, зумовлена необхідністю формування планів стратегічного розвитку підприємства. При цьому наявного інструментарію достатньо не лише для планування, але й для дієвого управління ефективністю діяльності працівників. Механізм такого управління включає у себе цілий комплекс заходів, які прямо або опосередковано впливають на ефективність персоналу організації (рис. 1).

Отже, практика оцінки ефективності управління та використання персоналу підприємства показує, що загальна сукупність методів та показників оцінки ефективності дозволяє проводити планування ефективного використання персоналу. При цьому можна зробити висновок, що до головних критеріїв оцінки ефективності відноситься підвищення продуктивності праці кожного працівника, що відображатиметься на загальному 
Економічні науки: збірник наукових пращь Луцького національного технічного університету. Серія "Регіональна економіка". Випуск 17 (67). Редкол.: відп. ред. к.е.н., професор І.В. Кривов’язюк. Луцьк: ІВВ Луцького НТУ, 2020. 348 с.

підвищенні продуктивності праці персоналу і матиме наслідок у вигляді зростання обсягу виробництва, зниження затрат на одну гривню продукції та призводитиме до загального зростання прибутку суб' єкта господарювання.

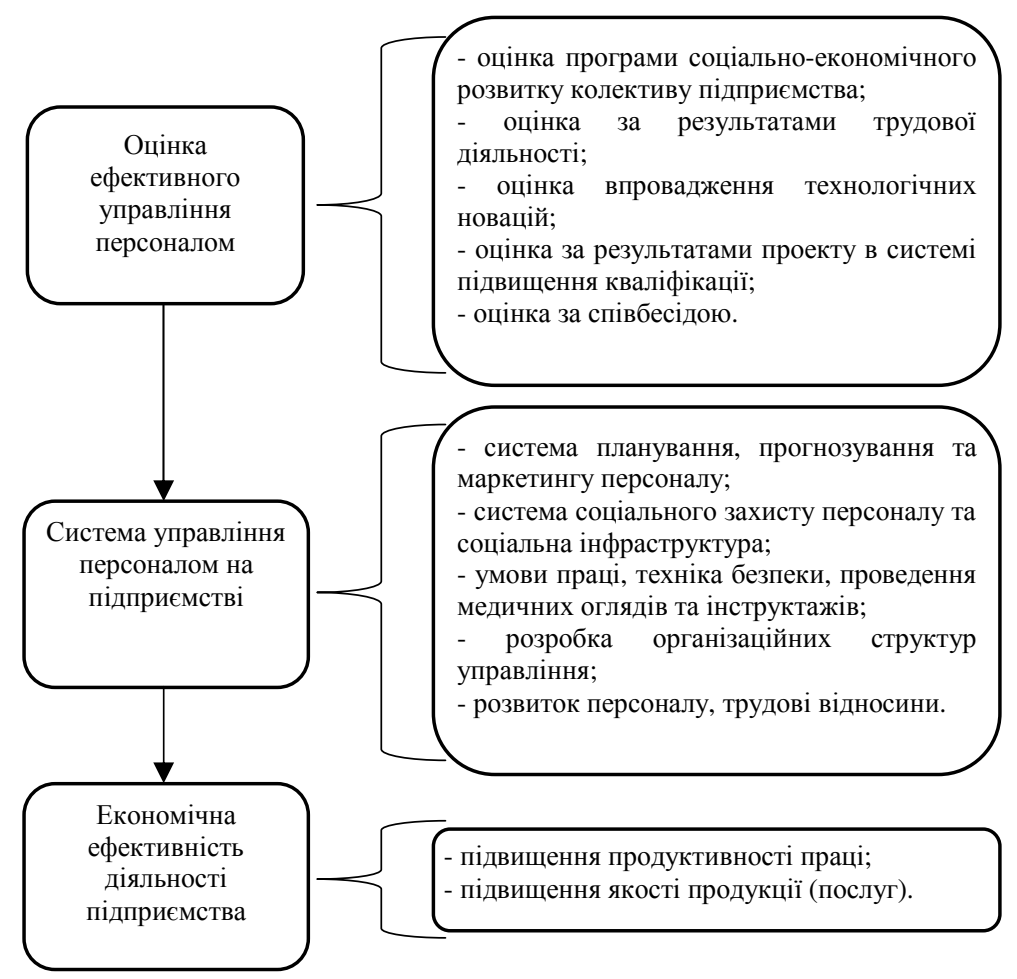

Рис. 1. Оцінка ефективності управління персоналу відносно загальної економічної ефективності діяльності підприємства

Джерело: [24]

Крім того, важливим аспектом оцінки ефективності управління персоналом підприємства $\epsilon$ планування та стимулювання персоналу до досягнення певних якісних 
Економічні науки: збірник наукових прачь Луиького національного технічного університету. Серія "Регіональна економіка". Випуск 17 (67). Редкол.: відп. ред. к.е.н., професор І.В. Кривов’язюк. Луцьк: ІВВ Луцького НТУ, 2020. 348 с.

показників діяльності, до яких відноситимуться як окремі цілі стратегічного розвитку підприємства, так і визначені в його рамках ключові показники ефективності, які зазвичай формуються в межах системи KPI (Key Performance Indicator).

Зрештою, останнім елементом оцінки ефективності управління персоналом підприємства $є$ визначення загальної задоволеності функціонування системи управління як самим персоналом, так і зовнішніми клієнтами підприємства.

Висновки. Таким чином, можна зробити висновок, що загальна ефективність використання персоналу підприємства на практиці розглядається як цілеспрямоване досягнення визначених в стратегічному плані конкретних результатів. При цьому результативність діяльності персоналу може бути виміряна за допомогою специфічних методів та 3 використанням конкретних показників, до головного 3 яких відноситься загальна продуктивність праці персоналу. Тому діяльність підприємства по налагодженню ефективної та дієвої системи управління персоналом $є$ одним 3 найважливіших завдань в аспекті досягнення стратегічних цілей суб'єкта господарювання.

\section{Список бібліографічного опису}

1. Полянов В.П., Воробьева И.С. Совершенствование оценки эффективности управления персоналом. Вісник Хмельнищького національного університету. Т. 3. Економічні науки. 2009. №6. С. 188-191 (рос. мовою).

\section{References}

1. Polianov V.P., Vorobiova I.S. Sovershenstvovanie otsenki effektivnosti upravlenia personalom [Improving the assessment of the effectiveness of personnel management]. Visnyk Khmelnytskogo natsionalnogo universytetu. T. 3 . Ekonomichni nauky - Bulletin of Khmelnytsky National University. T. 3. Economic sciences. 2009. Vol 6. Pp. 188-191 [in russian]. 